\title{
PENDIDIKAN KARAKTER BERBASIS KEARIFAN LOKAL HUMA BETANG \\ DALAM KEGIATAN PEMBELAJARAN ISMUBA KELAS X IPS DI SMA MUHAMMADIYAH KASONGAN
}

'Supriadi, ${ }^{2}$ Halpiani

\author{
1-2Fakultas Agama Islam, Universitas Muhammadiyah Palangkaraya
}

\section{ABSTRAK}

Penelitian ini difokuskan untuk mendeskripsikan: (I) Bagaimana pendidikan karakter berbasis kearifan lokal huma betang pada kegiatan pembelajaran ISMUBA kelas $X$ di SMA Muhammadiyah Kasongan?, (2) Bagaimana nilai karakter berbasis kearifan lokal huma betang dalam kegiatan pembelajaran ISMUBA kelas X IPS di SMA Muhammadiyah Kasongan?

Penelitian ini menggunakan pendekatan kualitatif, dan jenis penelitian deskriptif kualitatif, adapun subjek dalam penelitian ini adalah I (satu) orang guru ISMUBA, sedangkan informan dalam penelitian ini adalah Wakil Kepala Sekolah bagian kurikulum dan Kepala SMA Muhammadiyah Kasongan. Sekolah. Data yang dicari dalam penelitian ini dikumpulkan melalui teknik observasi langsung, wawancara dan dokumentasi yang divalidasi dengan Triangulasi, kemudian dianalisis melalui beberapa tahapan yaitu pengumpulan data, reduksi data, penyajian data, penarikan kesimpulan dan verifikasi.

Hasil di lapangan menunjukkan bahwa: (I). Pendidikan karakter di SMA Muhammadiyah Kasongan berjalan dengan baik ditandai dengan perubahan nilai-nilai filosofis Huma Betang seperti nilai kejujuran, kebersamaan, kerukunan, serta nilai taat hukum dan agama. (2) Nilai karakter yang muncul dari pendidikan karakter berbasis kearifan lokal huma betang dalam kegiatan pembelajaran ISMUBA kelas $X$ IPS di SMA Muhammadiyah Kasongan adalah nilai karakter disiplin, religi, religi, sosial, rasa ingin tahu, gemar membaca, kerja keras, tanggung jawab, kreatif, jujur, ramah/komunikatif dan penghargaan prestasi. Tugas guru ISMUBA dalam pendidikan karakter berbasis kearifan lokal adalah menjadi pendidik, pengajar dan pelatih. Terkait perannya sebagai motivator, direktur/direktur, inisiator, mediator, fasilitator dan evaluator

Kata kunci: Pendidikan karakter, kearifan lokal, dan pembelajaran ISMUBA

\section{ABSTRACT}

This research is focused to describe: (I) How is character education based on huma betang local wisdom in class $X$ ISMUBA learning activities at SMA Muhammadiyah Kasongan ?, (2) How is the value of character based on huma betang local wisdom in learning activities ISMUBA class $X$ IPS in high school Muhammadiyah Kasongan?

This study uses a qualitative approach, and the type of descriptive qualitative research, while the subjects in this study are I (one) ISMUBA teacher, while the informants in this study are the Vice Principal of the curriculum section and the Principal of Muhammadiyah Kasongan High School. The data sought in this study was collected through direct observation techniques, interviews and documentation which were validated by Triangulation, then analyzed through several stages namely data collection, data reduction, data presentation, drawing conclusions and verification.

The results in the field show that: (I). Character education at Muhammadiyah Kasongan High School went well with mark by changing the philosophical values of Huma Betang such as the value of honesty, togetherness, harmony, and also the value of observing the law and religion. (2) Character values that emerge from character education based on local wisdom huma betang in ISMUBA class X IPS learning activities at Muhammadiyah Kasongan High School are the character values of discipline, religion, religion, social, curiosity, fond of reading, hard work, responsibility, creative, honest, friendly / communicative and achievement awards. The task of ISMUBA teachers in character education based on local wisdom is to be an educator, teacher and trainer. Related to his role is as a motivator, director / director, initiator, mediator, facilitator and evaluator

Keywords: Character education, local wisdom, and ISMUBA learning 


\section{A. Pendahuluan}

Pendidikan memiliki posisi penting dalam kehidupan manusia. Mengingat pentingnya pendidikan bagi kehidupan manusia, maka Islam sebagai Agama yang rahmatan lil alamin, memberikan perhatian serius terhadap perkembangan pendidikan bagi kelangsungan hidup manusia. Dari pengertian di atas, dapat dipahami pendidikan memiliki tujuan yang luhur. Keluhuran tujuan tersebut selayaknya tercermin dari potensi diri yang tergali, sikap dan tingkah laku yang bermoral dari peserta didik selaku subyek pendidikan. Pendidikan yangada tidak hanya melahirkan seseorang yang ahli dalam bidang tertentuakan tetapi bagaimana seseorang mampu membawa diri dalam lingkungan bermasyarakat, berbangsa dan bernegara sesuai dengan norma dan aturan yang berlaku. Selain itu Seiring dengan adanya perkembangan globalisasi yang sedang berlangsung saat ini, mau tidak mau berdampak bagi kehidupan masyarakat di Indonesia. Kemajuan teknologi informasi telah membabat habis batas-batas yang mengisolasi kehidupan manusia. Karena itu, lahirlah masyarakat yang terbuka (open society), dimana terjadi aliran bebas informasi, yakni manusia, perdagangan, serta berbagai bentuk-bentuk aktivitas kehidupan global lainnya yang dapat menyatukan manusia dari berbagai penjuru dunia. Karena itu, masyarakat Indonesia mempunyai karakter tersendiri yang menjadi ciri khas dan berbeda dengan negara lain-nya, antara lain; I) keberagaman, 2) sikap saling pengertian, 3) toleransi 4) sanksi moral. Karakteristik ini diharapkan dapat mewarnai kehidupan sosial masyarakat Indonesia, sehingga dapat melahirkan masyarakat yang berpendidikan, berkarakter dan berbudaya.
Melalui dunia pendidikan inilah salah satu strategi dasar dari pembangunan karakter. Karakater bangsa yang kuat merupakan produk pendidikan yang baik. Tentunya akan menghasilkan manusia yang baik pula. ' Dalam kebijakan nasional pembangunan karakter bangsa tahun 2010-2025 ditegaskan bahwa karakter merupakan hasil keterpaduan empat bagian, yakni olah hati, olah pikir, olah raga, serta olah rasa dan karsa. Olah hati terkait dengan perasaan sikap dan keimanan, olah pikir berkenaan dengan proses nalar guna mencari dan menggunakan pengetahuan secara kritis, kreatif, dan inovatif, olah raga terkait dengan proses persepsi, kesiapan, peniruan, manipulasi, dan penciptaan aktivitas baru disertai sportivitas, serta olah rasa dan karsa berhubungan dengan kemauan dan kreativitas yang tercermin dalam kepedulian, pencitraan, dan penciptaan akan kebaruan. ${ }^{2}$ Sekolah (pendidikan) merupakan salah satu tempat strategis dalam pembentukan karakter selain di keluarga dan masyarakat. Melalui sekolah proses penanaman nilai-nilaikarakter siswa akan diaplikasikan baik melalui kegiatan belajar mengajar, budaya sekolah, maupun kegiatan pengembangan diri. Didalam kegiatan belajar mengajar siswa dihadapkan pada materi yang kaya akan nilai pendidikan karakter, baik dari aktivitas belajar langsung (materi) maupun tidak langsung seperti tingkah laku guru yang memberikan nilai pendidikan karakter misalnya religius seperti mengajak siswa untuk membaca do'a sebelum memulai pembelajaran. Dalam pembelajaran (materi) langsung terdapat banyak sekali nilai-nilai pendidikan karakter yang bisa siswa ambil, dan tugasguru menjabarkan nilai-nilai karakter yang dimaksud agar dapat diserap maksimal oleh 
Sebagai agen pembelajaran, guru diharuskan bukan hanya sekedar menguasai materi pelajaran tapi juga dituntut untuk memformulasikan kegiatan pembelajaran agar memilikimuatan nilai-nilai karakter di dalamnya, Salah satunya melalui pendidikan karakter yang berlandaskan kearifan lokal yang dapat diaplikasikan dalam kegiatan pembelajaran. Kearifan lokal yang mulai pudar dan terkikis oleh perkembangan jaman dan tergeser oleh budaya asing yang masuk dengan begitu pesat mempengaruhi karakter suatu bangsa, sehingga membuat kearifan lokal yang berkarakter di daerah tersebut perlahan ditinggalkan dan mungkin saja hilang nantinya. Melalui proses pembelajaran yang berkearifan lokal diharapkan dapat mengangkat kembali nilai-nilai budaya yang mulai tergeser oleh perkembangan zaman dan pengaruh budaya asing.

\section{B. Deskripsi Teoritik}

\section{Urgensi pendidikan karakter}

Menurut Kamus Besar Bahasa Indonesia, karakter merupakan sifat-sifat kejiwaan, akhlak atau budi pekerti yang membedakan seseorang dengan yang lain. Oleh karena itu, karakter adalah nilai yang unik baik yang terpatri dalam diri dan terejawantahkan dalam perilaku. Dalam pengertian sederhana pendidikan karakter adalah hal positif yang dilakukan guru dan berpengaruh kepada pserta didik yang diajarnya. Pendidikan karakter bukanlah pendidikan yang berbasis hafalan dan pengetahuan verbalistis, pendidikan karakter merupakan pendidikan perilaku yang terbentuk melalui habitual action dan pengejawatan keteladanan para pendidik, orang tua, para pemimpin, dan masyarakat yang merupakan anak.

\section{Nilai-nilai pendidikan karakter}

Dalam kajian kebudayaan, nilai merupakan inti dari setiap kebudayaan. Dalam konteks ini, khususnya nilai-nilai moral, merupakan sarana pengatur dari kehidupan bersama yang sangat menentukan sebuah budaya. Dalam nilai-nilai ini terdapat pembakuan tentang hal baik dan hal buruk serta pengaturan perilaku. Nilai-nilai hidup dalam masyarakat sangat banyak jumlahnya sehingga pendidikan berusaha membantu untuk mengenali, memilih dan menetapkan nilai-nilai tertentu sehingga dapat digunakan sebagai landasan pengambilan keputusan untuk berperilaku secara konsisten dan menjadi kebiasaan dalam hidup bermasyarakat.

Menurut Kementerian Pendidikan Nasional, Nilai karakter bangsa terdiri dari : Religius, jujur, toleransi, disiplin, kerja keras, kreatif, mandiri, demokratis, rasa ingin tahu, semangat kebangsaan, cinta tanah air, menghargai prestasi, bersahabat/komunikatif, cinta damai, gemar membaca, peduli lingkungan, peduli sosial dan tanggung jawab. ${ }^{5}$

\section{Hakikat pembelajaran ISMUBA}

(Islam, Muhammadiyah, Bahasa Arab)

Kawasan pendidikan Muhammadiyah, di antaranya terdiri dari ke-Islaman, kebangsaan, keutuhan, kebersamaan dan keunggulan merupakan kesatuan integral yang patut dikembangkan di setiap lembaga pendidikan Muhammadiyah. Mengapa keislaman ditempatkan dalam urutan pertama? Sebab, sejauh ini salah satu ciri pendidikan Muhammadiyah yang paling menonjol adalah bidang agama Islam. Ketiga pelajaran ini merupakan tulang-punggung Persyarikatan 
Supriadi, Halpiani. 202I Pendidikan Karakter Berbasis Kearifan Lokal Huma Betang Dalam Kegiatan Pembelajaran Ismuba Kelas X Ips Di Sma Muhammadiyah Kasongan

dalam rangka menyampaikan dakwah

Muhammadiyah. Kaderisasi Muhammadiyah secara intern berada dalam mata pelajaran Ismuba tersebut. Dalam pelajaran ini terdapat muatan yang bersifat ideologis, seperti yang terkandung dalam ke-Muhammadiyahan misalnya. Pelajaran Ismuba yang diajarkan pada peserta didik dalam masa dini adalah satu hal yang sangat tepat. Sebab, melalui mata pelajaran tersebut para peserta didik dapat mengetahui Risalah Islam dan dinamika gerakan Muhammadiyah dalam panggung sejarah nasional.

\section{Penguatan pendidikan karakter}

\section{berbasis kearifan lokal}

Penguatan dapat maknai sebagai suatu tindakan yang sengaja dilakukan untuk memperkuat sesuatu. Dalam Kamus Besar Bahasa Indonesia (KBBI), penguatan diartikan sebagai proses, cara, atau perbuatan untuk menguati atau menguatkan. Dalam buku Desain Induk Pendidikan Karakter dijelaskan bahwa dalam rangka mengembangkan kegiatan intervensi, pengintegrasian pendidikan karakter dilakukan kedalam semua materi pembelajaran.

Substansi nilai sesungguhnya secara eksplisit atau implisit sudah ada dalam rumusan kompetensi baik dalam Kompetensi Inti (KI) maupun Kompetensi Dasar (KD) dalam satuan pendidikan dasar dan pendidikan menengah. Yang perlu dilakukan lebih lanjut adalah memastikan bahwa pembelajaran materi pembelajaran tersebut memiliki dampak instruksional dan/atau dampak pengiring pembentukan karakter.

Praktik pendidikan karakter pada satuan pendidikan formal dan nonformal bukan hanya menjadi tanggung jawab materi pelajaran Pendidikan Agama atau Pendidikan
Kewarganegaraan (PKn). Inti dari Pendidikan Agama adalah pengembangan nilai iman, takwa, dan akhlak mulia. Adapun inti dari Pendidikan Kewarganegaraan (PKn) adalah pengembangan akhlak kewarganegaraan (civic virtue) yang mencakup kecerdasan kewarganegaraan (civic intelligennce), tanggungjawab kewarganegaraan (civic responsibility), dan partisipasi kewarganegaraan (civic participation). Selama ini terkesan materi pembelajaran lainnya hanya mengajarkan pengetahuan dari disiplin ilmu, teknologi, atau seni yang menaunginya. Oleh sebab itu, materi pembelajaran lain harus diperkuat dengan misi pendidikan karakter yang bersifat melekat dalam substansi dan proses keilmuan sebagai dimensi aksiologinya. Oleh karena itu, proses pembelajaran nilai-nilai karakter secara substantif diintegrasikan dalam setiap materi pembelajaran atau antar materi pembelajaran.

Pengembangan kualitas sumberdaya manusia, terutama di bidang pendidikanharus senantiasa menjadi prioritas pengembangan nasional maupun daerah. Dalam perkembangan konsepsi otonomi daerah, kewenangan pemerintah daerah dalam bidang pendidikan menjadi lebih luas, sungguhpun pada sisi lain otonomi daerah di bidang pendidikan membawa konsekuensi tanggung jawab lebih besar bagi pemerintah daerah.

Setidak-tidaknya terdapat tanggung jawab pemerintah daerah dalam hubungan dengan realisasi gagasan, kebijakan dan regulasi otonomi daerah dibidang pendidikan

Di Kalimantan tengah sendiri terdapat Cagar budaya yang merupakan warisan budaya kearifan lokal masyarakat Kalimantan tengah pada umumnya, yaitu "Huma Betang”. Huma Betang adalah rumah adat masyarakat 
Kalimantan Tengah. Rumah yang dibangun dengan cara gotong royong ini berukuran besar dan panjang mencapai 30 - 150 meter, lebarnya antara 10-30 meter, bertiang tinggi antara 3-4 meter dari tanah. Penghuni Huma Betang bisa mencapai seratus bahkan dua ratus jiwa yang merupakan satu keluarga besar dan dipimpin oleh seorang Bakas lewu atau Kepala Suku. Huma Betangdibuat tinggi dengan maksud untuk menghindari dari banjir, serangan musuh, dan juga binatang buas. Lantai dan dindingnya terbuat dari kayu, sedangkan dibagian atap terbuat dari sirap. Kayu yang dipilih untuk membangun Huma Betang ini ialah kayu ulin selain anti rayap, kayu ulin mampu bertahan hingga ratusan tahun.

Individu yang menetap di Huma Betang sangat menjunjung tinggi prinsip 4 Pilar Huma Betang. Layaknya 4 Pilar bangsa Indonesia yang menjadi karakteristik individu yang tinggal didalamnya, 4 Pilar karakteristik Huma Betang merupakan prinsip atau dasar pedoman dalam hidup bermasyarakat. 4 Pilar karakteristik tersebut sangat menjunjung tinggi nilai persatuan, kepatuhan, dan toleransi. Berikut ulasan mengenai 4 Pilar karakteristik Huma Betang :

a. Kejujuran,

b. Kebersamaan,

c. Kerukunan, dan

d. Taat hukum dan agama

Kejujuran menciptakan kebenaran, kebenaran mendorong terciptanya kebersamaan, kebersamaan tumbuh menciptakan persatuan, persatuan tumbuh dengan penuh rasa toleransi dan kerukunan. Kerukunan menciptakan kemenangan dalam menghadapi perbedaan. Ketaatan dan kepatuhan memperkuat jiwa untuk terus melaju dalam jalan yang lurus.

Kejujuran, kebersamaan, kerukunan, dan ketaatan yang dicerminkan oleh masyarakat suku Dayak menggambarkan karakteristik yang menjunjung tinggi semboyan "Bhineka Tunggal Ika" guna mencapai cita - cita "Mamangun Tuntang Mahaga Lewu" demi menciptakan Indonesia yang sejahtera dan berkarakter.

\section{Hasil Penelitian dan Pembahasan}

Di dalam pembahasan ini menguraikan mengenai bagaimana Pendidikan dan nilai- nilai karakter berbasis kearifan lokal huma betang dalam kegiatan pembelajaran ISMUBA di SMA Muhammadiyah Kasongan

\section{Pendidikan karakter berbasis}

\section{kearifan lokal huma betang dalam} kegiatan pembelajaran ISMUBA kelas X IPS di SMA Muhammadiyah

\section{Kasongan}

Terkait persiapan dari aspek perangkat pembelajaran, guru ISMUBA tersebut sudah melakukan persiapan dengan baik dari segi perangkat pembelajarannya. Dalam hal lain mengenai pengetahuan terhadap teori tentang pendidikan karakter, Guru ISMUBA tersebut mengetahui urgensi dari nilai-nilai karakter seperti fungsi dan dampak positifnya, selain itu beliau juga mengaplikasikan langsung karakter yang beliau ketahui tersebut. meskipun beliau tidak menyebutkan dan tidak hapal keseluruhan nilai-nilai karakter seperti yang ada di dalam teori, pengaplikasian langsung sikap dan prilaku yang di perlihatkan oleh DP selaku guru ISMUBA menjadinilai lebih.

Adapun bentuk kegiatan dalam membimbing atau mengarahkan peserta didik untuk memiliki nilai karakter beragam, tidak hanya di dalam kelas, namun juga di luar kelas. 
Supriadi, Halpiani. 202I Pendidikan Karakter Berbasis Kearifan Lokal Huma Betang Dalam Kegiatan Pembelajaran Ismuba Kelas X Ips Di Sma Muhammadiyah Kasongan

Tidak hanya tugas guru ISMUBA, tapi tugas seluruh dewan guru yang ada di SMA Muhammadiyah Kasongan. Meskipun jawaban yang diberikan oleh subjek dan informan terkesan umum dan tidak spesifik, namun bisa kita lihat dalam observasi kegiatan pembelajaran, baik dalam kelas maupun di luar kelas seperti kegiatan kepramukaan, organisasi yang ada di sekolah, dan lain-lain.

Kemudian Strategi khusus untuk membentuk karakter yang berlandaskan huma betang adalah disamping dengan program pembiasaan yang dapat menunjang karakter filosofis huma betang (kejujuran, kebersamaan, kerukunan, serta taat hukum dan agama) juga dengan mengemas RPP dengan muatan-muatan nilai karakter yang di harapkan.

Salah satu media yang digunakan dalam mengembangkan nilai karakter huma betang di sekolah SMA Muhammadiyah Kasongan adalah salah satunya lewat media "buku penghubung siswa". Buku penghubung siswa ini berfungsi untuk mengontrol kegiatan keagamaan siswa terutama yang beragama islam. Lewat buku penghubung siswa ini dapat menjadi media pengajaran dalam mengembangkan nilai-nilai karakter filosofis huma betang.

Bentuk usaha dan fasilitas yang dilakukan dalam mendukung dan berkembangnya nilai-nilai krakter filosofi Huma betang di SMA Muhammadiyah kasongan sudah sangat mendukung, dan fasilitas ini lagi-lagi tidak hanya mencakup didalam kelas namun juga diluar kelas, artinya usaha dan fasilitas yang diberikan dan diusahakan ini bersifat umum, atau dalam arti lain untuk seluruh siswa SMA Muhammadiyah pada umumnya, tidak dibatasi hanya kelas tertentu. Contohnya : dalam kelas ada yang Namanya tata tertib kelas, sebagai aturan bagi mereka untuk taat hukum yang telah dibuat bersama, hal ini akan menunjang kenyamanan kelas untuk menciptakan suasana belajar dan kebersamaan yang nyaman, mewujudkan toleransi dan kerukunan di kelas. Diluar kelas, nilai kejujuran sekolah menyediakan Namanya tempat pengaduan temuan barang, kemudian nilai kebersamaan sekolah menciptakan suasana kelas dan lingkungan sekolah yang bisa dan mudah diakses dan nyaman untuk terjadinya interaksi, kemudian siswa di arahkan untuk mau berorganisasi dan mengikuti ekskul supaya menciptakan suasana kebersamaan sehingga saling bekerjasama antar siswa. selanjutnya nilai kerukunan/toleransi sekolah memfasilitasi lewat perlakuan yang sama terhadap seluruh warga sekolah tanpa membedakan suku, ras, agama, status social, ekonomi. Lalu untuk menunjang nilai taat hukum dan agama, fasilitas yang sekolah berikan seperti, memiliki catatan kehadiran, kalaunya dalam kelas adanya tata tertib kelas tadi, imbauan-imbauan melalui kata-kata bijak di dinding-dinding kelas untuk taat aturan. terkait agama, adanya fasilitas tempat ibadah, dan selalu merayakan hari-hari besar keagamaan

\section{Nilai Dan Analisis Nilai Pendidikan}

Karakter Berbasis Kearifan Lokal

\section{Huma Betang Dalam Kegiatan Pembelajaran ISMUBA Kelas $X$ IPS di SMA Muhammadiyah Kasongan}

Untuk mendapatkan hasil penelitian terhadap nilai dan analisis nilai pendidikan karakter huma betang ini dalam kegiatan pembelajaran ISMUBA kelas $X$ IPS di SMA Muhammadiyah ini di lakukan dengan wawancara langsung terhadap subjek dan informan serta di dukung dengan data observasi dan dokumentasi. Hasilnya seperti 
yang di uraikan di bawah ini.

Guru ISMUBA di SMA Muhammadiyah punya metode tersendiri dalam mengintegrasikan nilai-nilai karakter kedalam kegiatan pembelajarannya, Dalam hal ini DP selaku guru ISMUBA di sekolah SMA Muhammadiyah melakukannya dengan cara pembiasaan dalam kegiatan pembelajarannya, seperti berdo'a setiap memulai pelajaran untuk menumbuhkan nilai-nilai karakter religius, taat hukum dan Agama.

Kemudian Guru ISMUBA membagi dua proses pembelajaran, yaitu didalam kelas dan diluar kelas, di dalam kelas terkait proses pembelajaran, sedangkan diluar kelas terkait aspek sikap prilaku siswa, kebiasaan dan kegitan siswa seperti ekskul dan organisaasi yang ada disekolah. Dari kedua kesempatan itulah menjadi kesempatan besar untuk menanamkan nilai-nilai karakter, khususnya nilai-nilai karakter kearifan lokal huma betang. Hal ini menggambarkan luasnya ranah pendidikan karakter di lingkup sekolah.

Kegiatan pembiasaan dalam penanaman nilai karakter kearifan lokal di SMA Muhammadiyah Kasongan beragam, bisa di dalam kelas maupun di luar kelas, seperti yang dijelaskan sebelumnya, dimana guru ISMUBA memberikan contoh kegiatan pembiasaan di dalam kelas (Kegiatan pembelajaran) dan di luar kelas (di luar kegiatan pembelajaran). Misalnya : lewat pembiasaan sholat berjamaah di masjid sekolah, menyediakan fasilitas Temuan barang, menciptakan suasana sekolah dan lingkungan yang nyaman dan mudah di akses, mengembangkan ekskul dan organisasi, hal ini baik menunjang nilai karakter filosofis huma betang yang sarat makna akan nilai kejujuran, kebersamaan, kerukunan serta taat hukum dan agama. Dari contoh-contoh yang disebutkan tadi adalah sebagian kecil dari banyak sekali kegiatan pembiasaan yang dilakukan di sekolah tersebut.

Adapun penilaian dari setiap pembelajaran, DP selaku guru ISMUBA menilainya yaitu melalalui 3 sisi : pengetahuan, keterampilan dan sikap. DP menjelaskan bahwa dalam pendidikan karakter bisa di nilai melalui penilaian sikap. Adapun indikator penilain sikap dapat dilihat melalai buku bobot poin siswa dan pengaplikasian niali-nilai karakter dalam sehari-hari terutama dilingkungan sekolah mulai dari mentaati tata tertib kelas dan sekolah, sampai dengan berprilaku baik dan sopan. Ketika sudah menjadi suatu kebiasaan di lingkungan sekolah, hal ini dapat terbawa di lingkungan lainnya seperti ranah keluarga dan masyarakat.

a. Muatan Nilai Pendidikan karakter berbasis kearifan lokal huma betang dalam kegiatan pembelajaran ISMUBA kelas $X$ IPS di SMA Muhammadiyah Kasongan

Pendidikan karakter berbasis kearifan lokal huma betang dalam kegiatan pembelajaran ISMUBA kelas $X$ IPS di SMA Muhammadiyah Kasongan berjalan baik dengan perencanaan kegiatan pembelajaran yang baik dan terencana pula. Hal ini dapat terlihat dari nilai-nilai karakter yang muncul di setiap pembelajarannya. Dengan mengusung visi dan misi penguatan karakter, maka nilai-nilai karakter yang lebih di tekankan dalam kegitan pembelajarannya, baik itu kegiatan pembelajaran didalam kelas maupun kegiatan pembelajaran diluar kelas.

$$
\text { Nilai karakter dalam kegiatan }
$$


Supriadi, Halpiani. 202I Pendidikan Karakter Berbasis Kearifan Lokal Huma Betang Dalam Kegiatan Pembelajaran Ismuba Kelas X Ips Di Sma Muhammadiyah Kasongan

pembelajaran ISMUBA di SMA Muhammadiyah

sangatlah luas, tidak hanya mencakup nilai-nilai karakter huma betang, artinya nilai-nilai filosofi karakter huma betang yang memiliki nilai kejujuran, kebersamaan, kerukunan/toleransi serta taat hukum dan agama ini merupakan bagian dari nilai nilai karakter yang di tanamkan oleh sekolah pada umumnya, dan oleh guru ISMUBA pada khususnya.

Adapun nilai karakter yang muncul lewat Pendidikan karakter berbasis kearifan lokal huma betang dalam kegiatan pembelajaran ISMUBA kelas X IPS di SMA Muhammadiyah Kasongan yaitu : disiplin, religius, toleransi, peduli sosial, rasa ingin tahu, gemar membaca, kerja keras, tanggung jawab, kreatif, jujur, bersahabat/komunikatif, dan menghargai prestasi.

b. Tugas dan Peran Guru ISMUBA dalam Penanaman Nilai Karakter Kearifan Lokal Huma Betang dalam Kegiatan Pembelajaran ISMUBA Kelas X IPS di SMA Muhammadiyah Kasongan

\section{I) Tugas guru ISMUBA dalam} penanaman karakter kearifan

\section{lokal .huma betang}

Tugas guru dalam penanaman nilai karakter pada peserta didik kelas X IPS di SMA Muhammadiyah Kasongan sudah terjalin dengan baik. Hal tersebut dapat dilihat dari aktivitas kegiatan pembelajaran didalam dan diluar kelas yang sudah memuat nilai-nilai karakter. Adapun tugas guru dalam hal ini yaitu memposisikan diri sebagai pengajar, pendidik dan sebagai pelatih.
2) Peran guru ISMUBA dalam penanaman karakter kearifan lokal .huma betang

Pada penelitian ini guru kurang memenuhi komponen kriteria peran guru dalam penanaman nilai karakter, khususnya karakter huma betang pada kegiatan pembelajaran, dari 9 (sembilan) peran yang semestinya harus dijalankan. pada kenyataannya guru hanya menjalankan 6 (enam) peran saja, yaitu: sebagai motivator, sebagai pengarah, sebagai inisiator, sebagai mediator,sebagai fasilitator, dan sebagai evaluator.

\section{Kesimpulan}

Berdasarkan penelitian di atas dapat disimpulkan bahwa :

I. Pendidikan karakter berbasis kearifan lokal huma betang dalam kegiatan pembelajaran ISMUBA kelas X IPS di SMA Muhammadiyah Kasongan berjalan baik dengan perencanaan kegiatan pembelajaran yang baik dan terencana pula. Hal ini dapat terlihat dari nilai-nilai karakter yang muncul di setiap pembelajarannya. Dengan mengusung visi dan misi penguatan karakter, maka nilainilai karakter yang lebih di tekankan dalam kegitan pembelajarannya, baik itu kegiatan pembelajaran didalam kelas maupun kegiatan pembelajaran diluar kelas seperti Ekstrakurikuler, Organisasi, dan kegiatan keagamaan.

Nilai karakter kearifan lokal huma betang dalam kegiatan pembelajaran ISMUBA kelas $X$ IPS di SMA Muhammadiyah Kasongan tercermin dari sikap dan prilaku yangmuncul di dalam kegiatan pembelajaran maupun di luar pembelajaran seperti berikut : 
a. Nilai kejujuran

I) Mengerjakan soal latihan dengan jujur tanpa menyontek,

2) Bertanya ketika tidak mengerti tentang materi yang sudah disampaiakan,

3) Menyerahkan barang temuan kepada petugas penjaga tempat temuan barang, dll.

b. Nilai Kebersamaan

I) Mengerjakan tugas kelompok,

2) Diskusi Kelas,

3) Aktif didalam organisasi-organisasi yangdibuat oleh sekolah seperti IMM,

4) Aktif dalam Ekstrakurikuler yang ada di sekolah seperti Pramuka, Drum band, Tapak Suci untuk mengasah kemampuan, menanamkan nilai kebersamaan dan kerjasama antar siswa.

c. Nilai kerukunan/toleransi

I) Menjaga suasana kelas tetap kondusif,

2) Saling Menghormati antar sesama siswa tanpa membedakan suku, ras, agama,maupun status sosial, dll.

d. Nilai taat hukum dan agama

I) Mematuhi tata tertib kelas dan tata tertib sekolah,

2) Menjalankan perintah agama, seperti menjalankan ibadah sholat berjamaah bagi yang beragama muslim.

2. Nilai karakter yang muncul dari Pendidikan karakter berbasis kearifan lokal huma betang dalam kegiatan pembelajaran ISMUBA kelas $X$ IPS di SMA Muhammadiyah Kasongan ini adalah nilai karakter disiplin, religius, toleransi, peduli sosial, rasa ingin tahu, gemar membaca, kerja keras, tanggung jawab, kreatif, jujur, bersahabat/komunikatif dan menghargai prestasi.

p-ISSN:2407-3865, e-ISSN:2655-1993

Dalam penanaman nilai karakter huma betang terhadap peserta didik kelas XIPS di SMA Muhammadiyah guru ISMUBA memiliki tugas dan peran sebagai berikut:

a. Tugas guru ISMUBA kelas X IPS di SMA Muhammadiyah dalam penanaman nilai karakter filosofi huma betang adalah sebagai pendidik, pengajar dan pelatih,

b. Peran guru ISMUBA dalam penanaman nilai karakter huma betang terhadap peserta didik kelas X IPS di SMA Muhammadiyah yaitu sebagai motivator, pengarah/director, inisiator, mediator, fasilitator dan evaluator.

\section{DAFTAR PUSTAKA}

Ghony dan Aimansyur, 2016, Metodologi penelitian kualitatif, Yogyakarta : Ar-Ruzz Media Kesuma Dharma, Cepi Triatna, Johar Permana, 2012, Pendidikan Karakter Kajian Teori dan Praktik di Sekolah. Bandung: PT. Remaja Rosdakarya

Koesoema Dhoni, 2007, Pendidikan

Karakter Strategi Mendidik Anak di

Zaman Global,Jakarta: PT

Gramedia Widiasarana Indonesia

Muslich Masnur, 20I I, pendidikan karakter 
Supriadi, Halpiani. 202I Pendidikan Karakter Berbasis Kearifan Lokal Huma Betang Dalam Kegiatan Pembelajaran Ismuba Kelas X Ips Di Sma Muhammadiyah Kasongan

menjawab tantangan krisis multidimensional,

Jakarta : Bumi Aksara

Ramayulis, Ilmu Pendidikan Islam, Jakarta: Kalam

Mulia, 2008

Salahudin Anas, 2013, Pendidikan

Karakter (pendidikan Berbasis

agama dan budayabangsa),

Bandung: CV Pustaka Setia

Sardiman, 20 I4, Interaksi dan Motivasi

belajar mengajar, Jakarta : PT Raja

GrafindoPersada

Samani Muchlas dan Hariyanto, 20I2,

Konsep dan Model Pendidikan

Karakter. Bandung:PT. Remaja

Rosdakarya
Sugiyono, 2015, Metode Penelitian Tindakan

Komprehensif (Untuk Perbaikan Kinerja danPengembangan Ilmu Tindakan).

Bandung: Alfabeta.

Sugiyono, 2016, Metode Penelitian Tindakan Komprehensif (Untuk Perbaikan Kinerja danPengembangan Ilmu Tindakan).

Bandung: Alfabeta

Sugiyono, 2019, Metode Penelitian

Kuantitatif, Kualitatif dan R\&D,

Bandung : Alfabeta,Cet. Ke-6

Supriadi Gito, 2015 Modul mata kuliah metodologi penelitian pendidikan,

Palangkaraya :Cetakan Pribad 